\title{
Bahan Ajar PPKn Berbasis Karakter dan Literasi untuk Siswa Kelas IX SMP Al Hikmah Surabaya
}

\author{
Sriyanto, Ibut Priono Leksono, Harwanto
}

Teknologi Pendidikan, Pascasarjana, Universitas PGRI Adi Buana Surabaya

\section{Edcomtech}

\section{Jurnal Kajian}

Teknologi Pendidikan

Volume 4, No 2, Oktober 2019

130-142

Submitted 29-06-2019

Accepted 28-08-2019

Corresponding Author

Sriyanto

otnay.jos@gmail.com

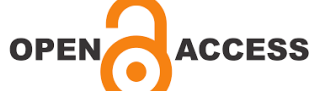

\begin{abstract}
Abstrak
Penelitian ini bertujuan menghasilkan bahan ajar PPKn Berbasis Karakter dan Literasi Siswa kelas IX yang dirancang lebih menarik, melatih mandiri, kreatif dan inovasi, sesuai kebutuhan siswa serta mengembangkan kompetensi, karakter dan literasi siswa. Model pengembangan yang digunakan Dick, Carey \& Carey (2001) yang disesuaikan dengan keperluan pengembangan. Teknik analisis ini digunakan untuk mengolah data yang diperoleh melalui lembar evaluasi dalam bentuk deskriptif persentase. Hasil validasi dari ahli desain pembelajaran mencapai $92.5 \%$. Sedangkan dari ahli materi bahan ajar yang dikembangkan mencapai $89.3 \%$. Hasil uji coba pada siswa, persentase kelayakan secara keseluruhan mencapai 83.66\%. Sedangkan Review dari guru mencapai 78.41\% serta respon melalui angket mendapatkan respon sangat baik. Dari data dan analisis yang telah dilakukan dapat disimpulkan bahwa produk pengembangan dapat digunakan sebagai bahan ajar pada mata pelajaran Pendidikan Pancasila dan Kewarganegaraan (PPKn) yang memiliki kualifikasi sangat baik, dan mengembangkan ranah kompetensi, karekater dan literasi siswa.
\end{abstract}

Kata Kunci: Pengembangan bahan ajar PPKn, pendidikan karakter, literasi siswa

\begin{abstract}
This study aims to produce teaching materials based on Character and Literacy PPKn Class IX students who are designed to be more interesting, to train independently, creatively and innovatively, according to students 'needs and develop students' competence, character and literacy. The development model used by Dick, Carey \& Carey (2001) adjusted to the development needs. This analysis technique is used to process data obtained through evaluation sheets in the form of descriptive percentages. The validation results from learning design experts reached $92.5 \%$. While the experts of teaching materials developed reached $89.3 \%$. The results of trials on students, the overall eligibility percentage reached $83.66 \%$. While the Review from the teacher reached $78.41 \%$ and the response through the questionnaire got a very good response. From the data and analysis that has been done, it can be concluded that the development product can be used as teaching material in Pancasila and Citizenship Education (PPKn) subjects that have very good qualifications, and develop the domains of competence, character and student literacy.
\end{abstract}

Keywords: Development of PPKn teaching materials, character education, student literacy 


\section{PENDAHULUAN}

Kurikulum yang dibuat oleh pemerintah merupakan salah satu elemen penting untuk mewujudkan kompetensi siswa yang diharapkan dalam pembelajaran. Menurut Harun (2017) dalam evaluasi kurikulum 2013, ada tiga hal yang harus dicapai kurikulum yakni harus mengembangkan ranah kompetensi, karakter, dan literasi.

Pada ranah kompetensi diperlukan sebagai instrumen untuk mengarahkan siswa proaktif menjawab tantangan kehidupan yang serba kompleks, dan persaingan global yang tak bisa dihindari, mengharuskan siswa mampu memiliki kompetensi dengan berpikir kritis, kreatif, komunikatif dan kolaboratif. Pada ranah penguatan karakter siswa diharapkan mampu menghadapi zaman yang selalu berubah, dan mengatasi degradasi moral bangsa. Salah satu solusi yang tepat mengedepankan pendidikan karakter. (Ahyar, 2019;75). Pendidikan karakter yang kembangkan oleh pemerintah saat ini adalah religius, nasionalis, integritas mandiri, dan gotong royong.

Menurut Asriani $(2017 ; 1457)$ dalam proses pembelajaran siswa tidak sekedar menguasai kompetensi yang ditargetkan, tetapi lebih dari itu siswa harus mampu menginternalisasikan nilai-nilai dalam mata pelajaran bisa diterapkan dalam kehidupan sehari-hari. Hal yang senada juga disampaikan oleh Ghufron (2010) menyampaikan bahwa pengintegrasian nilai-nilai karakter bangsa ke dalam kegiatan pembelajaran, dengan cara memadukan, memasukkan, dan menerapkan nilai-nilai diharapkan dapat membentuk kepribadian peserta didik sesuai jati diri bangsa.

Sedangkan pengembangan ranah literasi diharapkan siswa mampu mengaplikasikan ketrampilan dalam kehidupan sehari-hari. Baik literasi baca tulis, sains, literasi informatika, literasi budaya dan kewarganegaraan. Menurut Suyono $(2009 ; 204)$ literasi sangat dibutuhkan siswa untuk menyelesaikan studi, melanjutkan studi, mempersiapkan diri memasuki dunia pekerjaan, dan belajar sepanjang hayat di tengah masyarakat. Oleh karena itu, sangat beralasan apabila literasi dijadikan basis pengembangan kegiatan pembelajaran di sekolah.
Ada tiga tahapan dalam gerakan literasi disekolah. Pertama, Tahap Pembiasaan. Pembiasaan bisa dilakukan dengan cara menumbuhkan semangat membaca dikelas setiap pagi. Kedua, Tahap Pengembangan. Bisa dilakukan dengan meningkatkan kemampuan literasi melalui kegiatan menanggapi buku pengayaan. Ketiga, Tahap Pembelajaran. setiap mata pelajaran ada muatan literasi saat pembelajaran atau pengayaan. (Kemendikbud;2016).

Pada tahap ketiga ini, guru memiliki peran penting dalam gerakan literasi melalui pembelajaran dengan membuat bahan ajar yang berbasis literasi. Dalam konteks pengembangan bahan ajar berbasis literasi pembelajaran bertujuan; (1) meningkatkan kemampuan memahami teks, dikaitkan dengan pengalaman pribadi sehingga menjadi siswa pembelajar sepanjang hayat; (2) mengembangkan kemampuan berpikir kritis. (3) mengolah dan mengelola kemampuan komunikasi secara kreatif melalui kegiatan menanggapi teks buku bacaan dan buku pelajaran.

Berdasarkan hasil penelitian Gipayana (2004) dan Suryanto (2010) dalam Aisyah (2017; 668) menunjukan bahwa konsep pembelajaran yang mengembangkan literasi dapat meningkatkan kualitas pembelajaran membaca, menulis, dan melatih berpikir kritis.

Untuk mencapai tujuan arah baru kebijakan kurikulum 2013 dan paparan diatas, maka diperlukan suatu kegiatan pembelajaran berbasis karakter dan literasi dengan cara memasukan nilai-nilai karakter dan kegiatan literasi dalam pembelajaran. Salah satu bagian penting dalam keberhasilan dalam proses pembelajaran adalah bahan ajar.

Bahan ajar merupakan instrument penting dalam kegiatan belajar mengajar untuk mencapai tujuan yang diharapkan. Menurut Ridwan $(2016 ; 168)$ Bahan ajar sebagai salah satu sumber belajar yang dapat mendukung proses dan pencapaian kompetensi yang ingin dicapai. Selain itu bahan ajar bisa mendorong semangat belajar siswa.

Secara definisi bahan ajar adalah segala bahan yang didesain secara sistematis, 
berdasarkan kompetensi yang dicapai siswa, dan digunakan dalam proses pembelajaran serta ada evaluasi pembelajaran (Prastowo 2012:17). Senada dengan Lestari (2013: 2) bahan ajar adalah sekumpulan materi pelajaran berdasar pada kurikulum yang digunakan dalam rangka mencapai tujuan pembelajaran yang telah ditentukan.

Sedangkan pendapat Majid (2013: 174), bentuk bahan ajar setidaknya dapat dikelompokkan menjadi empat yaitu: (1) Bahan cetak misalnya handout, buku, modul, dan lembar kerja siswa. (2) Bahan ajar audio seperti kaset, dan compact disk audio. (3) Bahan ajar audio visual seperti video atau film. (4) Bahan ajar interaktif seperti media interaktif.

Pada mata pelajaran Pendidikan Pancasila dan Kewarganegaraan (PPKn), buku siswa dan buku pendidik sudah disediakan oleh pemerintah untuk memenuhi standar minimal untuk mencapai Standar Kompetensi Lulusan (SKL), Kompetensi Inti (KI), dan Kompetensi Dasar (KD). Menurut Winataputra (2016) dalam Ikhsan (2017) bahwa PPKn merupakan mata pelajaran memiliki tujuan pembentukan bangsa agar bisa memahami, dan mampu melaksanakan hak-hak dan kewajibannya. Selain itu tujuan mata pelajaran untuk menjadikan bangsa Indonesia yang cerdas, terampil, dan berkarakter yang sesuai kepribadian bangsa.

Berdasarkan observasi penulis bersama teman sejawat, dalam menggunakan bahan ajar PPKn khususnya kelas IX yang telah disediakan masih memiliki standar minimal, kurang memenuhi kebutuhan siswa, kurang variatif, baik dari segi desain, bahan bacaan, konteks dan pendalaman materi (latihan dan pengayaan).

Oleh karena itu sangat perlu adanya pengembangan bahan ajar yang sesuai dengan kondisi, kebutuhan, dan tingkat kompetensi siswa. Pengembangan bahan ajar merupakan kegiatan sistematik dalam merancang, mengevaluasi, menghubungkan fakta, konsep, prinsip, atau teori yang terkandung dalam mata pelajaran berdasarkan kompetensi dasar yang dicapai (Mbulu dan Suhartono,
2004:5). Pendidik bisa memperkaya materi yang tersedia dengan berbagai macam kreasi, dan memasukan nilai-nilai karakter dan literasi sesuai karakteristik, dan kemampuan siswa.

Salah satu cara pengembangan bahan ajar bisa adaptasi bahan ajar yang ada, tetapi ditambahkan sesuai kreasi dengan mengembangkan nilai karakter dan literasi dalam pembelajaran. Menurut Wibowo (2013:179) cara mudah membuat bahan ajar berbasis karakter dengan cara mengadopsi bahan ajar ada dengan dengan mengintegrasikan nilai karakter yang dinginkan.

Adanya kesenjangan antara kenyataan dan harapan, hal inilah yang mendorong penulis mengembangkan bahan ajar PPKn memiliki desain lebih menarik, melatih kemandirian, kreatif dan inovasi, sesuai kebutuhan siswa dengan mengembangkan kompetensi, karakter dan literasi siswa.

\section{METODE}

Jenis penelitian ini adalah penelitian dan pengembangan yang berorientasi menghasilkan produk berupa bahan ajar, yaitu bahan ajar PPKn berbasis karakter dan literasi Siswa kelas IX semester II SMP AI Hikmah Surabaya.

Model pengembangan yang digunakan dalam penelitian ini menggunakan teori Dick, Carey \& Carey (2001) yang disesuaikan dengan keperluan pengembangan. Menurut Handayani $(2017 ; 18)$ desain pengembangan oleh Dick, Carey \& Carey menekankan penerapan prinsip desain instruksional disesuaikan dengan tahapan yang harus di tempuh secara sistematis. Sedangkan Menurut Degeng (2013:6) dalam Wahyuni $(2018 ; 107)$ menyampaikan bahwa bahan ajar harus di rancang dengan model pengembanan tertentu, dan memasukan materi pembelajaran dari berbagai sumber karena dengan perancangan yang baik akan berpengaruh pada kualitas pembelajaran. Bahan ajar yang dirancang dengan baik dapat meningkatkan hasil belajar (Resvathi, Degeng, N.S dan Kuswandi: 2017). 


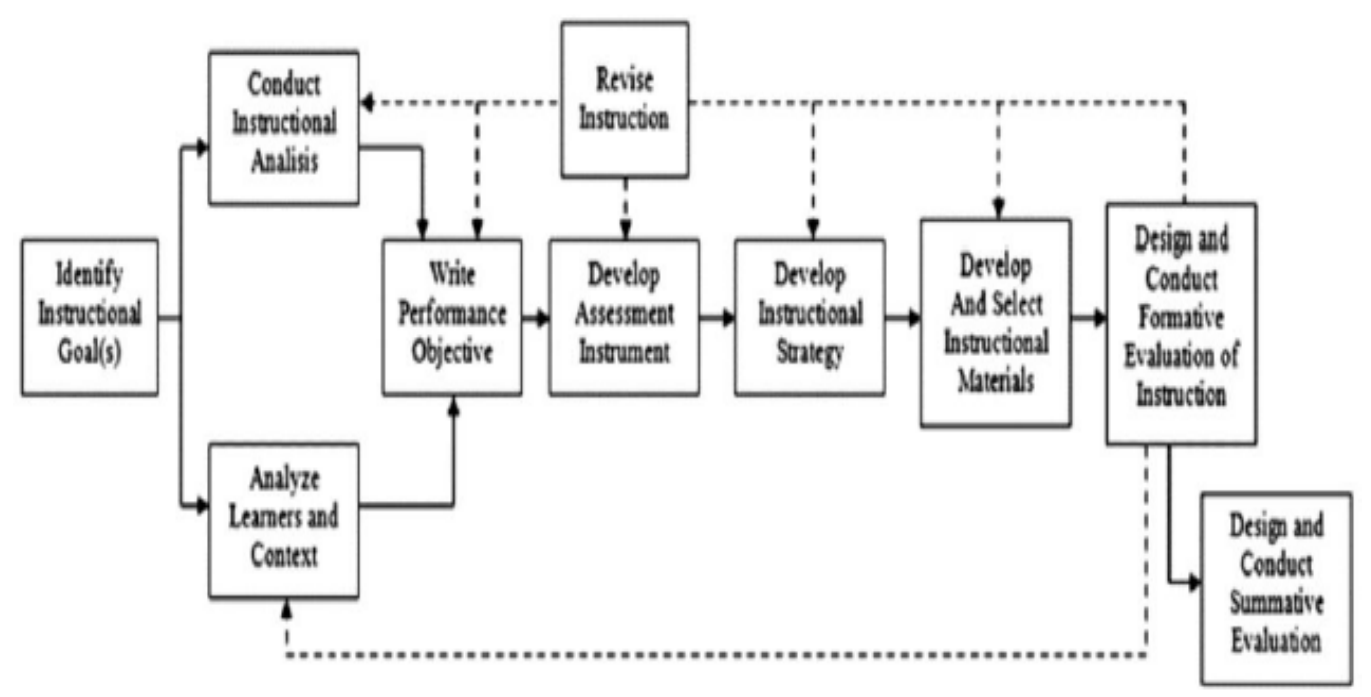

Gambar 1; Alur Pengembangan Model Dick, Carey, \& Carey (2001)

Model ini memiliki prinsip pemecahan masalah belajar yang terprogram, jelas tahapannya, dan dirancang secara sistematis. Ada Sembilan langkah yang dilakukan, yaitu: (1) mengidentifikasi tujuan instruksional umum, (2) melakukan analisis pembelajaran, (3) mengidentifikasi prilaku dan karakteristik siswa, (4) merumuskan Tujuan Pembelajaran Khusus, (5) mengembangkan item-item tes acuan patokan, (6) mengembangkan strategi pembelajaran, (7) mengembangkan dan menulis bahan pembelajaran, (8) mendesain dan melaksanakan evaluasi formatif, (9) merevisi kegiatan.

Prosedur pengembangan yang digunakan dalam pengembangan bahan ajar ini adalah melalui lima tahap, yaitu: Pertama, menetapkan mata pelajaran yang akan dikembangkan. Mata pelajaran yang dikembangkan adalah bahan ajar PPKn kelas IX SMP Semester II. Kedua, mengidentifikasi kurikulum mata pelajaran PPKn yang akan dikembangkan. Mengidentifikasi silabus dengan tetap memperhatikan Kompetensi Inti dan Kompetensi Dasar. Identifikasi ini bertujuan untuk menentukan pokok-pokok bahasan yang diharapkan dimiliki oleh siswa pada mata pelajaran PPKn.

Tahap Ketiga, mengembangkan bahan ajar PPKn dengan langkah-langkah sebagai berikut: (1). Mengidentifikasi tujuan pembelajaran, yaitu apa yang akan dilakukan siswa setelah mengikuti pelajaran, (2). Menganalisis pelajaran dengan tujuan mengetahui keterampilan siswa yang ingin diharapkan dalam tujuan pembelajaran, (3). Mengidentifikasi karakteristik siswa. Tujuannya untuk mengetahui karakteristik dan keterampilan yang dimiliki sebelum pembelajaran dimulai, dengan cara observasi, (4). Merumuskan tujuan pembelajaran yang didasarkan pada analisis pembelajaran (5) Mengembangkan materi pembelajaran dalam bentuk bahan ajar. Tahap Keempat, menyusun bahan ajar. Tahap Kelima, uji coba produk yang meliputi review ahli media pembelajaran, ahli materi/isi, ahli desain pembelajaran, uji coba kelompok kecil, dan uji coba lapangan siswa dan review guru.

Agar bahan ajar dari proses pengembangan bisa digunakan sebagai media pembelajaran yang efektif sesuai harapan, diperlukan validasi dan uji coba terlebih dulu. Oleh karena itu bahan ajar yang telah disusun dan ditulis divalidasi dan diuji coba dalam beberapa tahap, yaitu:

a. Validasi ahli desain pembelajaran, untuk mendapatkan penilaian komentar serta saran terhadap ketepatan desain pembelajaran, desain isi (konsistensi tata letak, unsur tata letak lengkap,tipografi isi buku) dan ilustasi isi dalam pembelajaran.

b. Validasi ahli materi, untuk memperoleh data berupa penilaian, pendapat dan 
kritik terhadap kelayakan isi, kelayakan penyajian, kelayakan bahasa dalam bahan ajar yang akan dibuat.

c. Uji coba kelompok kecil, bertujuan untuk menentukan apakah siswa dapat menggunakan bahan ajar tanpa adanya interaksi guru. Selama tahap ini, pengembang bekerja dengan sembilan siswa yang merupakan wakil dari populasi sasaran. Sembilan siswa tersebut terdiri dari tiga siswa dengan prestasi belajar tinggi, tiga siswa dengan prestasi belajar sedang, dan tiga siswa dengan prestasi belajar rendah. Kemudian siswa menilai bahan ajar ini dari aspek tampilan, aspek penyajian materi, dan aspek manfaat. Pada proses ini pengembang hanya berperan menjawab pertanyaan siswa yang memerlukan penjelasan dalam mengisi lembar evaluasi.

d. Review guru, bertujuan untuk mendapatkan saran dan kritik terhadap isi ketepatan isi materi dan tugas yang diberikan pada siswa dapat membantu pemahaman siswa.

e. Ujicobalapangan(tryoutdikelas), bertujuan untuk mendapatkan situasi belajar yang sesungguhnya dalam pembelajaran. Tahap akhir ini untuk mengukur apakah revisi yang telah dibuat pada uji coba kelompok kecil sudah efektif, dan apakah bahan ajar dapat dipraktekan dalam pembelajaran di kelas sesuai harapan.

Penelitian ini, menggunakan jenis data yakni (1) hasil valiadasi ahli desain pembelajaran, dan ahli isi mata pelajaran PPKn (2) data hasil uji coba kelompok kecil, dan hasil review guru pengajar PPKn serta hasil uji coba lapangan.

Sedangkan teknik analisis data ini adalah analisis isi. Analisis ini untuk mengelompokkan informasi data kualitatif dari hasil lembar evaluasi ahli media, ahli materi/isi, ahli desain pembelajaran, lembar evaluasi yang diisi oleh siswa dan guru, hasil diskusi, dan hasil konsultasi. Sedangkan data kuantitatif yang diperoleh dianalisis dengan teknik deskriptif berupa rerata persentase.

Analisis data tiap komponen baik data hasil penilaian ahli, data hasil penilaian kelompok dan hasil penilaian lapangan/try out dilakukan dengan analisis deskriptif berupa rerata dan presentase. Hasil penilaian ahli dihitung persentase tingkat pencapaiannya dengan menggunakan rumus :

$$
\begin{gathered}
\text { Persentase }= \\
\frac{\sum(\text { Jawaban } \times \text { bobot tiap pilihan })}{n \times \text { bobot tertinggi }} \times 100 \%
\end{gathered}
$$

Keterangan:

$\Sigma=$ jumlah

$\mathrm{n}=$ jumlah seluruh item angket

$\%=$ menjelaskan Tingkat ekspresi

Langkah berikutnya menghitug persentase keseluruhan subyek digunakan rumus:

Persentase $=F: N$

Keterangan:

$\mathrm{F} \quad=$ Jumlah persentase keseluruhan subyek

$\mathrm{N} \quad$ = banyak subyek

Untuk dapat memberikan makna dan pengambilan keputusan tingkat kelayakan produk digunakan ketetapan sebagai berikut:

\section{Konversi Tingkat Pencapaian dengan Skala 4 (Diadaptasi dari Arikunto, 2013)}

\begin{tabular}{|c|c|c|}
\hline $\begin{array}{c}\text { Tingkat } \\
\text { Pencapaian }\end{array}$ & Kualifikasi & Keterangan \\
\hline $76 \%-100 \%$ & Sangat Baik & $\begin{array}{c}\text { Tidak perlu } \\
\text { direvisi }\end{array}$ \\
\hline $51 \%-75 \%$ & Baik & $\begin{array}{c}\text { Tidak perlu } \\
\text { direvisi }\end{array}$ \\
\hline $26 \%-50 \%$ & Kurang Baik & Direvisi \\
\hline $0 \%-25 \%$ & Tidak Baik & Perlu revisi \\
\hline
\end{tabular}

\section{HASIL DAN PEMBAHASAN}

Hasil pengembangan produk bahan ajar PPKn berbasis karakter dan literasi ditampilkan bagian penting atau keunggulanya diantaranya sebagai berikut; 


\section{PENDIDIKAN PANCASILA DAN KEWARGANEGARAAN (PPKn) BERBASIS KARAK'T'ER DAN LIT'TRARI}

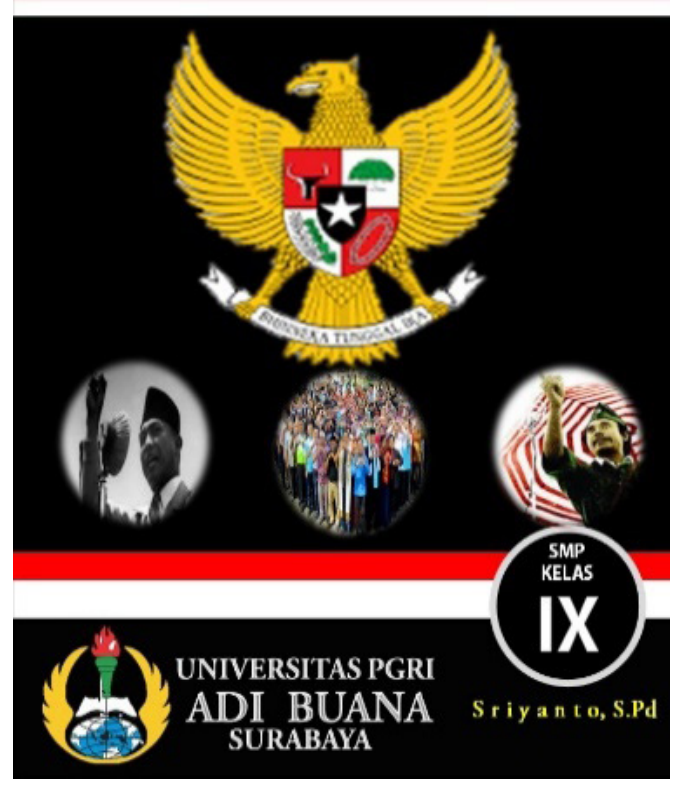

Gambar 2. Cover depan bahan ajar

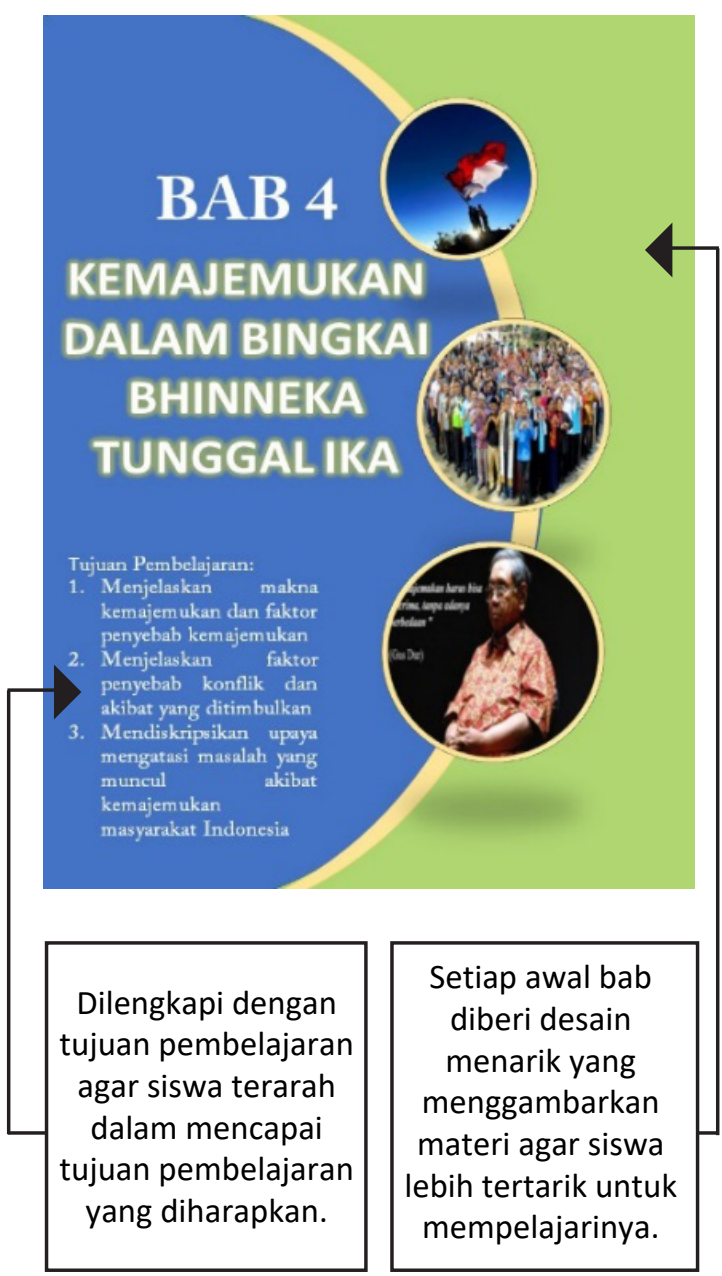

Gambar 3. Sub Judul dan Tujuan Pembelajaran
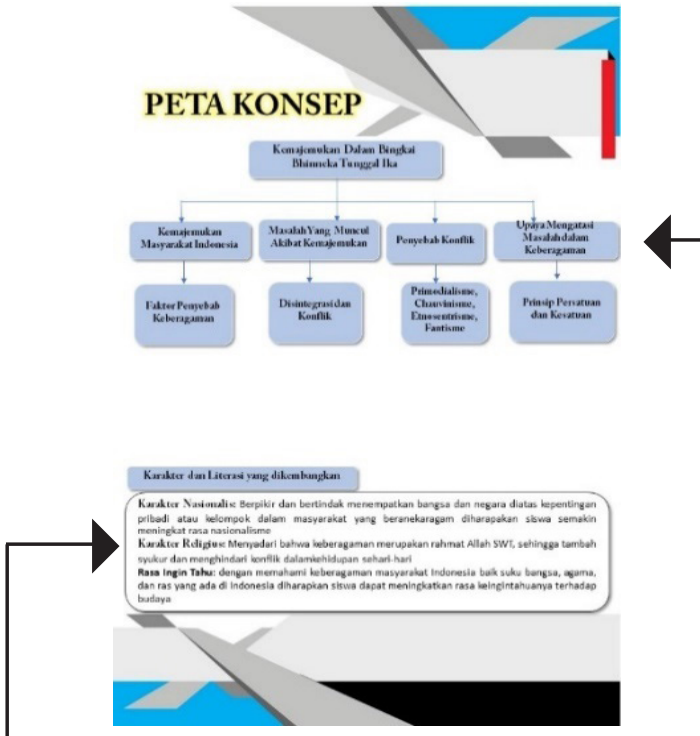

Fitur Karakter dan literasi yang dikembangkan ditampilkan agar siswa mengetahui nilai karakter dan literasi yang ditanamkan

Fitur Peta konsep untuk mempermudah pemahaman dan alur pembahasan sehingga membawa siswa untuk lebih belajar efektif

Gambar 4. Peta Konsep dan Karakter Yang ditanamkan

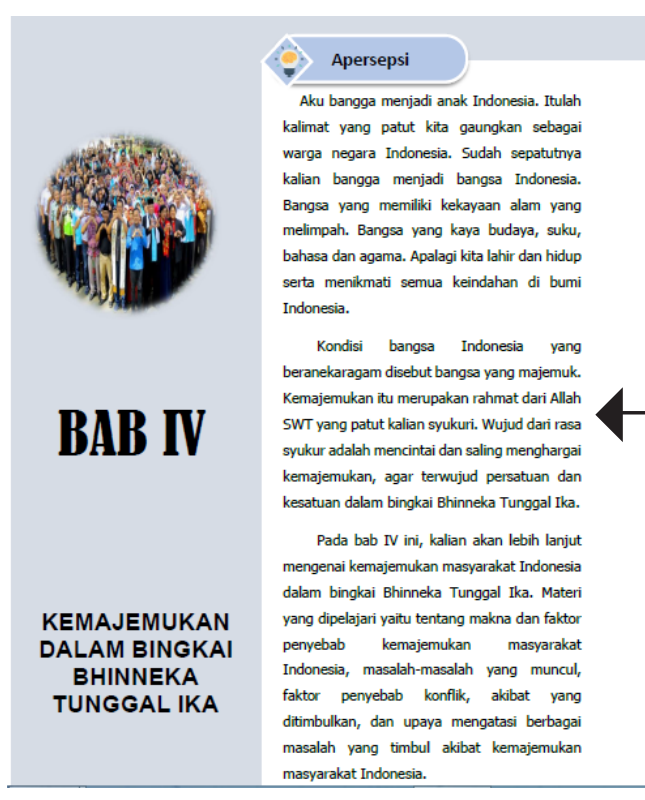

Sebelum pembelajaran dimulai, selalu diawali apersepsi dengan maksud sebagai koneksi terhadap materi yang akan dipelajari dan bentuk pembelajaran kontekstual yang menghubungkan antara dunia sehari-hari dengan materi yang akan dipelajari.

Gambar 5. Apersepsi 


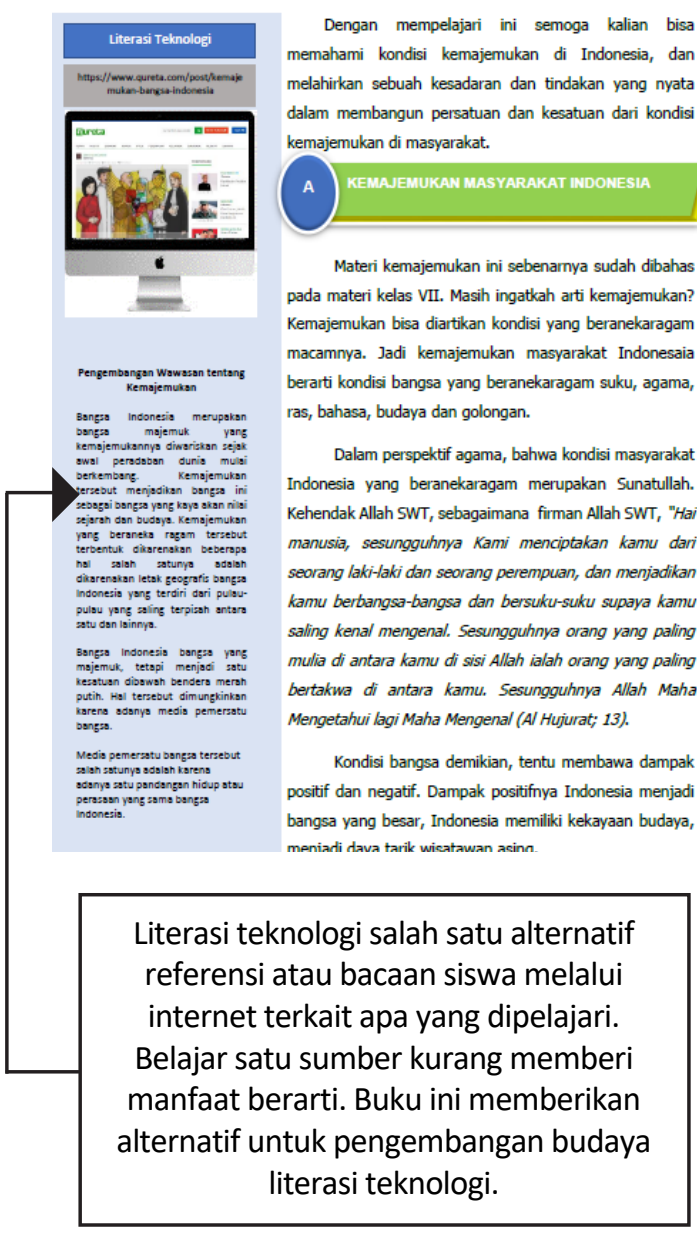

Gambar 6. Literasi Teknologi

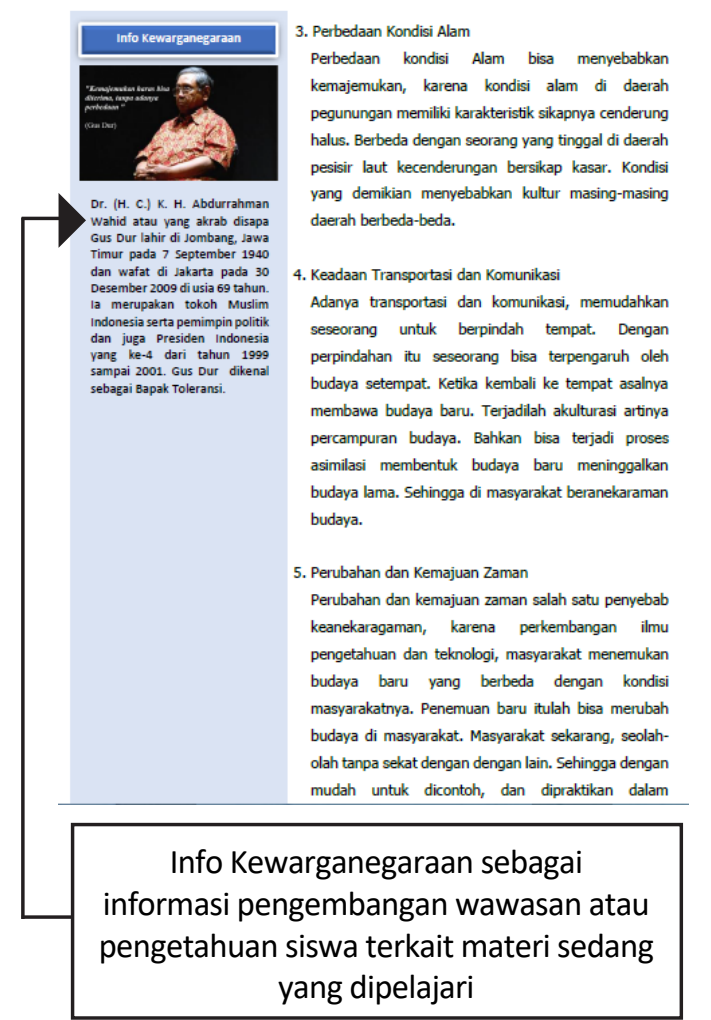

Gambar 7. Info Kewarganegaraan

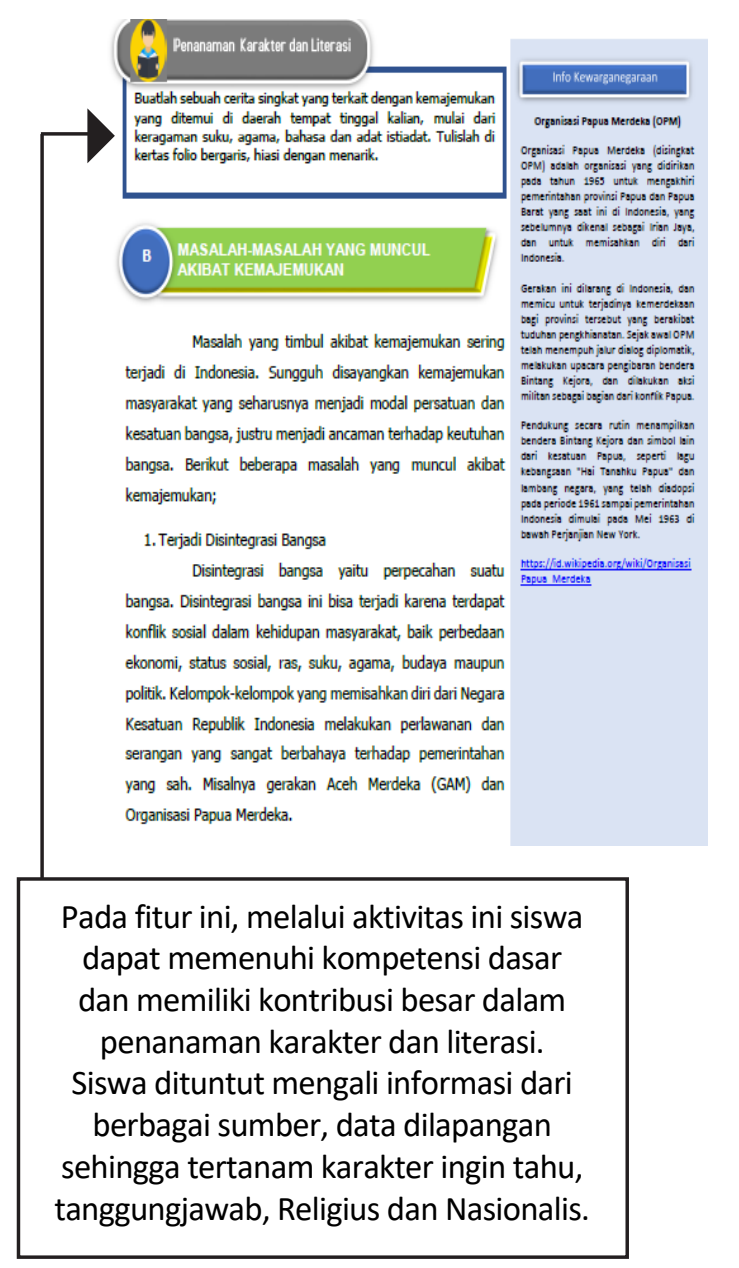

Gambar 8. Pengembangan Karakter dan Literasi

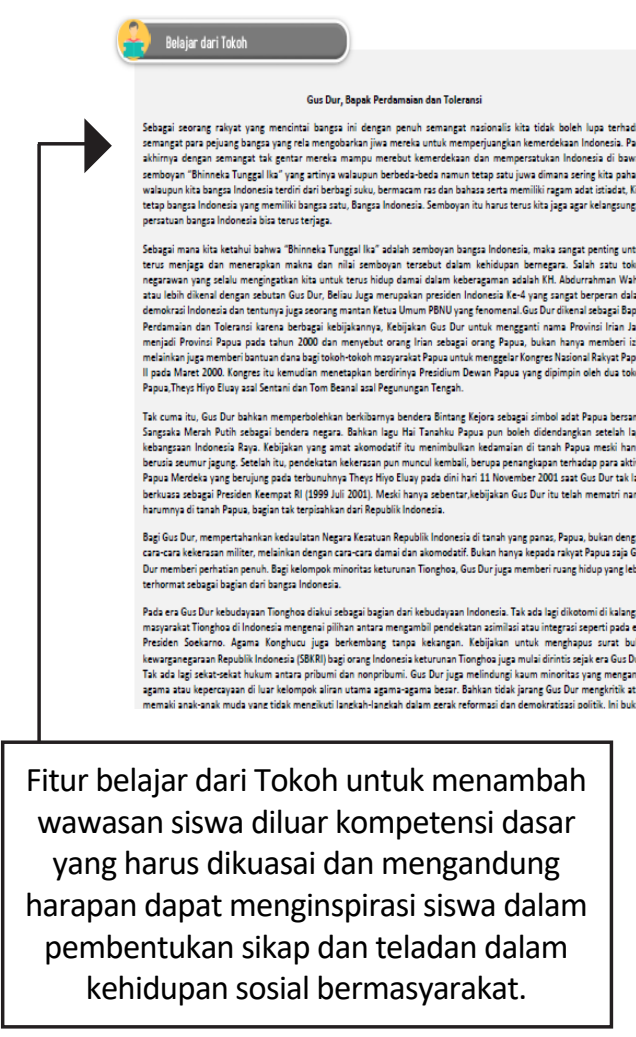

Gambar 9. Belajar dari Tokoh 


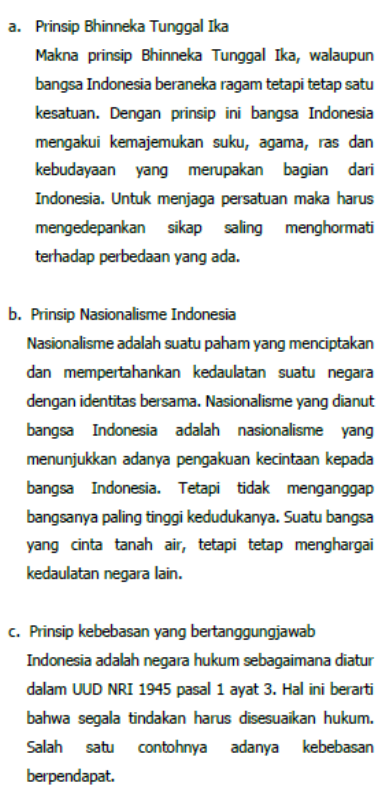

Kolom kata-kata motivasi yang diambil dari beberapa tokoh ini ditampilkan guna menambah semangat belajar siswa untuk lebih memahami semangat perjuangan para tokoh dahulu.

\section{Gambar 10. Kata-kata Motivasi}

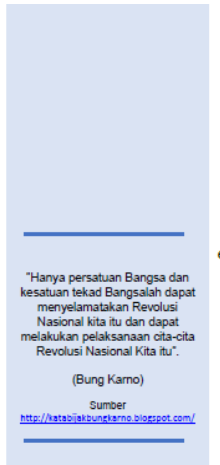

bangsa Indonesia mengenai diri dan lingkungannya berdasarkan Pancasila dan UUD NRI 1945. Dalam wawasan nusantara, manusia ditempatkan dalam kedudukan kerangka kesatuan politik, sosial budaya, hukum, ekonomi setta pertahanan dan keamanan. Kesatuan tersebut membentuk perasaan senasib dan sepenanggungan, muncul suatu tekad mencapai pembangunan nasional.

e. Prinsip Persatuan mewujudkan cita-cita reformasi. Reformasi merupakan langkah awal kehidupan bangsa yang demokratis. Reformasi menginginkan penvelenggaraan pemerintah Indonesia didasarkan pada demokrasi Pancasila dan pelaksanaan UUD NRI 1945. Agenda penting era reformasi penegakan supermasi hukum, pemberantasan Korupsi, Kolusi dan nepotisme (KKN), amademen konstitusi. (Winataputra;2012)

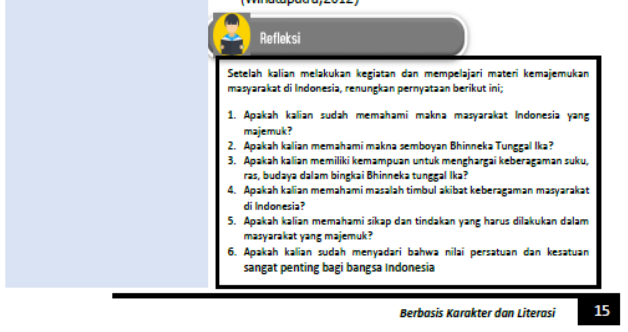

Fitur Reflkesi ini sebagai bahan muhasabah diri terkait apa yang dipelajari untuk mengetahui pada bagian mana materi yang belum dan sudah dipahami sehingga memudahkan reteaching, dan siswa fokus pada materi yang belum paham.

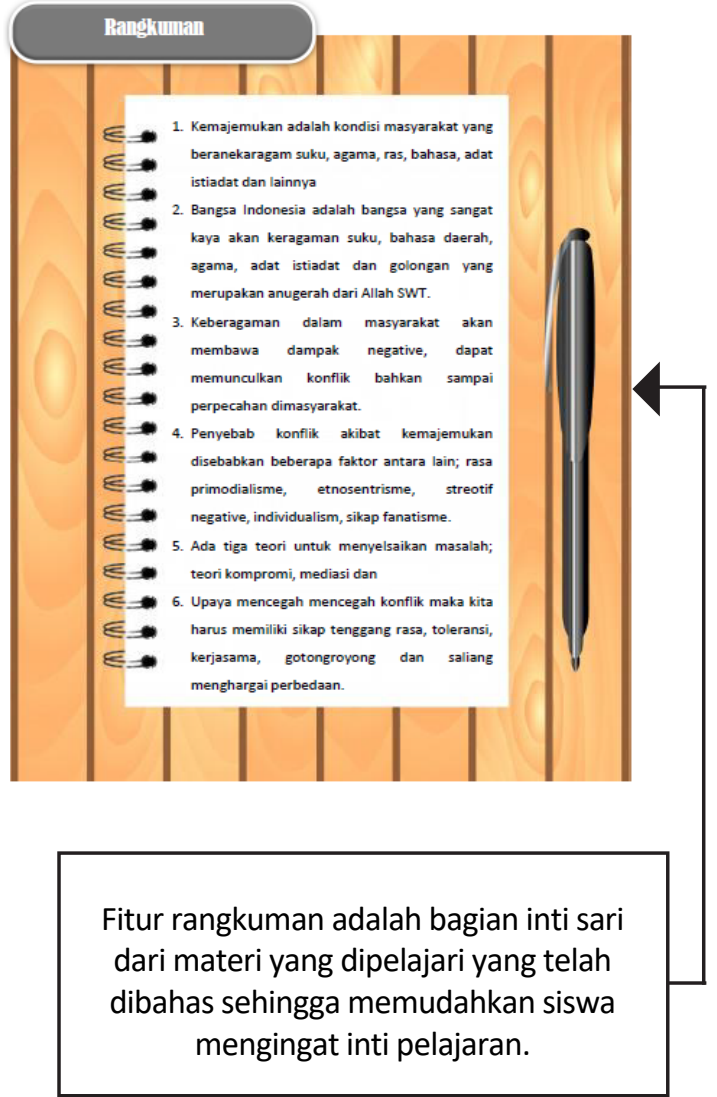

Gambar 12. Rangkuman

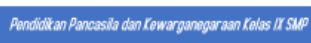

\section{Uji Kompetensi}

A. Pilihlah salah satu jawaban yang paling tepat!

1. Masyarakat Indonesia merupakan masyarakat majemuk yang terdiri dari beraneka ragam suku, bangsa, adat dan budaya mudah menimbulkan konflik, maka sikap yang harus di miliki oleh warga negara adalah ... A. toleransi terhadap perbedaan SARA yang ada di masyarakat B. memberi santunan dan bantuan bagi yang membutuhkan

C. mendahuluan kepentingan warga yang berprestasi demi kemajuan masyarakat

D. mengutamakan pembangunan dipelosok-pelosok tanah air

2. Suatu pertentangan yang diakibatkan oleh perbedaan adat istiadat, norma sosial dan budaya dalam masyarakat adalah merupakan konflik.... A. antar agama

B. antar suku

C. antar golongan D. antar ras

3. Dengan adanya kemajemukan masyarakat Indonesia, maka yang harus kita waspadai adalah ....

A. Segala bentuk ganguan yang menguntungkan pihak lain B. Segala bentuk ancaman yang dapat memecah belah bangsa Indonesia C. Segala bentuk tantangan yang dapat mempersatukan bangsa Indonesia D. Segala bentuk ancaman yang dapat merugikan kelompok tertentu

Fitur uji kompetensi ini disajikan setiap akhir bab sebagai sarana mengukur kemampuan siswa pada aspek kognitif, apakah tujuan pembelajaran sudah tercapai apa belum.

Gambar 13. Uji Kompetensi 


\section{Validasi Ahli Desain Pembelajaran}

Validator Ahli desain pembelajaran bahan ajar ini oleh Dr. Drs. A. Noor Fatirul, S.T. M.Pd. beliau adalah seorang Doktor bidang Teknologi Pembelajaran di Universitas
Negeri Malang, dan bertugas sebagai dosen Program Studi Teknologi Pendidikan Program Pascasarjana Universitas PGRI Adi Buana Surabaya. Berikut ini tabel hasil validasi dari ahli desain pembelajaran.

Tabel 1. Rekap Hasil Penilaian Ahli Desain Pembelajaran

\begin{tabular}{|c|c|c|c|c|c|}
\hline No & Aspek Penilaian & $\begin{array}{c}\text { Rerata Hasil } \\
\text { Skor/ Skor } \\
\text { Maksimal }\end{array}$ & $\mathbf{P ~ ( \% )}$ & Kategori & Keputusan Uji \\
\hline 1. & Ukuran bahan ajar & $8 / 8$ & $100 \%$ & Sangat baik & $\begin{array}{c}\text { Tidak perlu } \\
\text { direvisi }\end{array}$ \\
\hline 2. & Desain sampul (Cover) & $31 / 36$ & $86,2 \%$ & Sangat baik & $\begin{array}{c}\text { Tidak perlu } \\
\text { direvisi }\end{array}$ \\
\hline 3. & Desain isi bahan ajar & $74 / 80$ & $92,5 \%$ & Sangat Baik & $\begin{array}{c}\text { Tidak perlu } \\
\text { direvisi }\end{array}$ \\
\hline \multicolumn{3}{|c|}{ Rerata total analisis } & $92.9 \%$ & Sangat baik & $\begin{array}{c}\text { Tidak perlu } \\
\text { direvisi }\end{array}$ \\
\hline
\end{tabular}

Berdasarkan data analisis pada tabel 1 . Menunjukkan bahwa aspek ukuran bahan ajar mencapai nilai persentase 100\% (sangat baik), desain sampul/cover bahan ajar memperoleh nilai persentase $86,2 \%$ (sangat baik), dan desain isi bahan ajar mencapai nilai persentase 92,5\% (sangat baik). Dari data diatas, secara keseluruhan persentase rerata total hasil analisis penilaian ahli isi/materi mencapai 92,9\%.

Hal ini berarti semua aspek penilaian mencapai kualifikasi sangat baik dan keputusan ujinya adalah tidak perlu direvisi. Secara umum ahli desain pembelajaran menyimpulkan bahwa bahwa desain bahan ajar PPKn yang dihasilkan layak dijadikan salah satu instrumen penelitian tesis dan bisa diuji dilapangan. Ada beberapa catatan dengan font lebih variasi, warna harus kontras, gambar lebih ditambah sebagai ilustrasi, dan agar dicetak full colour.

\section{Validasi Ahli Isi/ Materi}

validator ahli isi/ materi pada bahan ajar ini adalah Dr. Suhari, S.H, M.Si. beliau adalah seorang Doktor yang menjadi Dosen Jurusan PPKn Universitas PGRI Adi Buana Surabaya. Selain itu juga menjabat sebagai Dekan Fakultas Keguruan dan IImu Pendidikan Universitas PGRI Adi Buana Surabaya. Berikut ini tabel hasil validasi dari ahli Isi/ Materi

Tabel 2. Rekap Hasil Penilaian Ahli Isi/Materi

\begin{tabular}{|c|c|c|c|c|c|}
\hline No & Aspek Penilaian & $\begin{array}{c}\text { Rerata Hasil } \\
\text { Skor/ Skor } \\
\text { Maksimal }\end{array}$ & P (\%) & Kategori & Keputusan Uji \\
\hline 1. & Kelayakan isi & $26 / 28$ & $92,8 \%$ & Sangat baik & Tidak perlu direvisi \\
\hline 2. & $\begin{array}{l}\text { Kelayakan penyajian } \\
\text { materi }\end{array}$ & $36 / 36$ & $100 \%$ & Sangat baik & Tidak perlu direvisi \\
\hline 3. & Kelayakan Bahasa & $30 / 40$ & $75 \%$ & Baik & Tidak perlu direvisi \\
\hline \multicolumn{3}{|c|}{ Rerata total analisis } & $89,3 \%$ & Sangat baik & Tidak perlu direvisi \\
\hline
\end{tabular}


Hasil analisis pada tabel 2 menunjukkan bahwa nilai persentase untuk aspek kelayakan isi bahan ajar mencapai 92,8\% (sangat baik). Aspek kelayakan penyajian bahan ajar mencapai nilai persenatse $100 \%$ (sangat baik). Sedangkan untuk aspek kelayakan bahasa mencapai nilai 75\% (baik). Secara keseluruhan persentase rerata total hasil analisis penilaian ahli isi/materi mencapai 89,3\%.

Berdasarkan hasil tersebut, berada pada kualifikasi sangat baik dan keputusan ujinya tidak perlu direvisi. Komentar dan saran tertulis dari ahli isi/materi agar lebih teliti dalam menuliskan kata, teliti dalam menyusun kalimat, pertimbangkan cakupan dan kedalaman materi dan jika mengambil sumber dari sumber lain,tunjukkan asalnya. Semua saran dan masukan dari ahli isi dijadikan acuan dan bahan pertimbangan penyempurnaan atau revisi terhadap pengembangan bahan ajar.

\section{Hasil uji coba kelompok kecil}

Sebelum dilakukan uji coba lapangan, maka bahan ajar diuji cobakan pada kelompok kecil yang terdiri dari sembilan siswa. Berikut ini adalah hasil analisis data yang sudah dipersentasekan:

\section{Tabel 3. Rekap Hasil Uji Coba Kelompok Kecil}

\begin{tabular}{|c|l|c|c|c|c|}
\hline No & Aspek Penilaian & $\begin{array}{c}\text { Rerata Hasil } \\
\text { Skor/ Skor } \\
\text { Maksimal }\end{array}$ & $\mathbf{P ~ ( \% )}$ & Kategori & Keputusan Uji \\
\hline 1. & $\begin{array}{l}\text { Kelayakan } \\
\text { tampilan }\end{array}$ & $21.24 / 24$ & $88.5 \%$ & Sangat baik & Tidak perlu direvisi \\
\hline 2. & $\begin{array}{l}\text { Kelayakan } \\
\text { penyajian materi }\end{array}$ & $43.65 / 52$ & $83.94 \%$ & Sangat baik & Tidak perlu direvisi \\
\hline 3. & Manfaat & $21 / 24$ & $87.5 \%$ & Sangat Baik & Tidak perlu direvisi \\
\hline \multicolumn{2}{|c|}{ Rerata total analisis } & $86.65 \%$ & Sangat baik & Tidak perlu direvisi \\
\hline
\end{tabular}

Dari tabel 3 diatas dapat diketahui bahwa kelayakan tampilan persentase $88.5 \%$, penyajian materi $83.94 \%$ dan manfaat mencapai nilai persentase $87.5 \%$. Rerata skor analisis $86.65 \%$, artinya lebih dari $76 \%$. Dengan demikian semua aspek penilaian memiliki kualifikasi sangat baik dan keputusan ujinya adalah tidak perlu direvisi.

Sedangkan komentar dan saran dari uji kelompok kecil terangkum sebagai berikut; Gambar dan warna menarik sehingga memotivasi untuk membaca buku, Font cukup bagus. Ilustrasi cukup menarik, bahan ajar Menarik, Tulisannya kurang besar, Lebih baik banyak gambar dan variasi font lebih banyak, Buku paket lebih to the point, lebih baik banyak soal latihannya agar membuat waktu belajar lebih singkat

\section{Hasil uji coba lapangan}

Bahan ajar ini di uji cobakan pada kelas IX B yang jumlahnya 30 siswa. Pada saat pelaksanaan tanggal 10 Juni 2019 yang hadir 28 siswa, ada dua siswa yang tidak masuk karena sakit. Teknis pelaksanaanya, sebelumnya penulis menginformasikan bahwa ada uji coba bahan ajar PPKn Berbasis Karakter dan Literasi. Kemudian penulis, mengajarkan satu kompetensi dasar pelajaran. Langkah selanjutnya siswa diminta mengisi lembar evaluasi untuk diisi sesuai apa yang dirasakan dari aspek kelayakan tampilan, kelakyaan penyajian materi dan manfaat. Hasil penilaian siswa terhadap bahan ajar sebagaimana disajikan dalam tabel; 
Tabel 4. Rekap Hasil Uji Coba Lapangan

\begin{tabular}{|c|l|c|c|c|c|}
\hline No & Aspek Penilaian & $\begin{array}{c}\text { Rerata Hasil } \\
\text { Skor/Skor } \\
\text { Maksimal }\end{array}$ & $\begin{array}{c}\mathbf{P} \\
\mathbf{( \% )}\end{array}$ & Kategori & Keputusan Uji \\
\hline 1. & $\begin{array}{l}\text { Kelayakan } \\
\text { tampilan }\end{array}$ & $19.70 / 24$ & $82.08 \%$ & Sangat baik & Tidak perlu direvisi \\
\hline 2. & $\begin{array}{l}\text { Kelayakan } \\
\text { penyajian materi }\end{array}$ & $43.11 / 52$ & $83.90 \%$ & Sangat baik & Tidak perlu direvisi \\
\hline 3. & Manfaat & $20.40 / 24$ & $85.00 \%$ & Sangat Baik & Tidak perlu direvisi \\
\hline \multicolumn{2}{|r|}{ Rerata total analisis } & $\mathbf{8 3 . 6 6 \%}$ & Sangat baik & Tidak perlu direvisi \\
\hline
\end{tabular}

Berdasarkan hasil rekap uji coba lapangan menunjukan persentase aspek kelayakan tampilan bahan ajar mencapai $82.08 \%$ (sangat baik); aspek penyajian materi bahan ajar memperoleh nilai 83.90\% (sangat baik); aspek manfaat dari bahan ajar mencapai $85.00 \%$ (sangat baik). Secara keseluruhan persentase (P) dari rerata total analisis mencapai $83.66 \%$. Berdasarkan Tabel 5 juga menyebutkan bahwa nilai $P$ pada setiap aspek yang di uji mencapai lebih dari $76 \%$. Nilai tersebut masuk dalam kategori sangat baik, dan diputuskan untuk tidak revisi.

Sedangkan komentar dan saran dari uji coba lapangan dirangkum dari sebagai berikut ini; Desain bukunya berwarna, mudah dipelajari, menarik, dan sangat efektif, lebih banyak gambar dan warna agar tidak membosankan, ukuran tulisan lebih besar sehingga mudah dilihat dan dipahami, variasi font lebih banyak, ilustrasi gambar ditambah agar lebih bagus, materi sangat ringkas, sesuai dengan tujuan pembelajaran, banyak wawasan yang didapatkan karena ada kolom literasi bisa mencari informasi di internet, ada tugas yang menanamkan nilai karakter dan literasi, bahasanya yang sulit dipahami, lebih disederhanakan, bacaannya seru dan terlihat menarik, contoh kasus yang terbaru terjadi dimasyarakat, ada kata-kata motivasi, membuat belajar lebih semangat, tugas lebih banyak kelompok sehingga terbangun kerjasama, bahan ajar ini melatih berpikir kritis, menuntut kreatifitas dan melatih belajar mandiri siswa, dan kalau bisa ditambahkan video studi kasus .

Kesimpulan yang diberikan oleh para siswa yang menjadi peserta uji coba lapangan adalah sebagai berikut: (1) Semua peserta uji coba lapangan menyatakan bahwa mereka tertarik dengan bahan ajar ini. (2) Sepuluh peserta menyatakan bahwa buku ajar ini sangat baik digunakan dalam pembelajaran PPKn (tanpa revisi). (3) Sedangkan delapan belas peserta menyatakan bahwa bahan ajar ini baik digunakan dalam pembelajaran PPKn karena mengembangkan nilai karakter dan literasi.

\section{Hasil Review guru mata pelajaran}

Agar bahan ajar ini lebih sempurna, maka juga meminta masukan dan saran dari teman sejawat yang mengajar mata pelajaran PPKn dengan pertimbangan bahwa guru mata pelajaran lebih merasakan langsung saat pembelajaran dikelas.

Oleh karena itu penulis, memohon pada Ustadz Zaenal Abidin dan Ustadz Suhartadji sebagai guru mata pelajaran PPKn di SMP Al Hikmah Surabaya utnuk mereview bahan ajar PPKn Kelas IX Berbasis Karakter dan Literasi. Hasil penilaian dua guru terhadap bahan ajar ditunjukan dalam tabel berikut ini. 
Tabel 5. Rekap Review Guru Mapel

\begin{tabular}{|c|l|c|c|c|c|}
\hline No & Penilai & $\begin{array}{c}\text { Rerata Hasil } \\
\text { Skor/ Skor } \\
\text { Maksimal }\end{array}$ & P (\%) & Kategori & Keputusan Uji \\
\hline 1. & Guru 1 & $33 / 44$ & $75.0 \%$ & baik & Tidak perlu direvisi \\
\hline 2. & Guru 2 & $36 / 44$ & $81.81 \%$ & Sangat baik & Tidak perlu direvisi \\
\hline \multicolumn{2}{|r|}{ Rerata total analisis } & $78.41 \%$ & Sangat baik & Tidak perlu direvisi \\
\hline
\end{tabular}

Berdasarkan data diatas, secara keseluruhan persentase $(P)$ dari rerata total analisis penilaian guru mencapai $78.41 \%$. Nilai tersebut masuk dalam kategori sangat baik, dan diputuskan untuk tidak revisi.

Selain memberikan penilaian, guru mata pelajaran juga diperkenankan memberikan komentar dan saran untuk perbaikan bahan ajar. Berikut disajikan komentar dan saran dari guru terhadap bahan ajar. (1) Bahan ajar ini tampilanya sudah kekinian. Tinggal diperbanyak aplikasi karakternya. (2) Siswa bisa melihat studi kasus cukup baik. Bisa dilengkapi dengan contoh kasus yang lagi viral atau update. (3) Tugas dan latihan kelompok lebih banyak agar lebih terampil dalam memecahkan masalah. (4) diharapkan lebih banyak contoh aplikasi dalam kehidupan masyarakat, (5) Bahasa dalam bahan ajar ini sederhana dan runtut.

\section{SIMPULAN}

Dari data dan analisis hasil validasi ahli desain pembelajaran, ahli isi/materi, uji coba kelompok kecil, dan uji coba lapangan siswa, dan review guru terhadap pengembangan bahan ajar ini, dapat ditarik kesimpulan bahwa bahan ajar ini ditinjau dari aspek isi dan desain pembelajaran memiliki kualifikasi sangat baik dan tidak perlu revisi. Penilaian dari aspek desain pembelajaran menunjukkan persentase $92,5 \%$. Sedangkan aspek isi atau materi menunjukkan persentase $89,3 \%$. Pada uji coba lapangan yang diikuti oleh 28 siswa mencapai persentase kelayakan mencapai $83.66 \%$. Sedangkan skor yang diberikan oleh guru mencapai persentase $78.41 \%$. Untuk dapat memberikan makna dan pengambilan keputusan tingkat kelayakan produk digunakan konversi tingkat pencapaian dengan Skala 4 (diadaptasi dari Arikunto, 2013). Maka dari data tersebut menunjukkan masuk dalam kategori sangat baik, dan diputuskan untuk tidak revisi. Selain itu berdasarkan komentar dan saran siswa dan guru bahan ajar ini didesain lebih menarik, melatih kemandirian, kreatif, inovasi, dan siswa belajar lebih efektif, serta dapat mengembangkan pada ranah kompetensi, karakter dan literasi siswa.

Bahan ajar ini disusun berdasarkan karakteristik siswa kelas IX SMP Al Hikmah Surabaya sehingga apabila digunakan untuk siswa dari sekolah lain perlu ada penyesuaian. Sekaligus perlu dikembangkan buku panduan untuk guru agar bahan ajar bisa dimanfaatkan dengan maksimal.

\section{DAFTAR PUSTAKA}

Ahyar, Sihkabuden.,\& Yerri Soepriyanto. 2019. Implemtasi Model Pembelajaran Based Learning pada Mata elajaran Pendidikan Pancasila dan Kewarganegaraan (PPKn). JINOTEP (Jurnal Inovasi Teknologi Pembelajaran) April 2019. (http://journal2.um.ac.id/index.php/ jinotep/article/view/6898/3691/) diakses 21 Maret 2019.

Aisyah, D., Muhana Gipayana., EriTri Djatmika. 2017. Pengembangan Bahan Ajar berbasis Literasi Bercirikan Quantum Teaching Untuk Mengoptimalkan Pembelajaran Efektif dan Produktif. Jurnal Pendidikan: Teori Penelitian, dan Pengembangan. Mei 2017. Halaman: 667-675. (http://journal.um.ac.id/ 
index.php/jptpp/diakses 13 April 2019)

Arikunto, S. 2013. Dasar-dasar Evaluasi Pendidikan. Jakarta: Bumi Aksara.

Asriani, P., Cholis Sa'dijah.,\& Sa'dun Akbar. 2017. Bahan Ajar Berbasis Karakter Untuk Siswa Kelas IV Sekolah Dasar. Jurnal Pendidikan: Teori, Penelitian, dan Pengembangan. Volume: 2 Nomor: 11 Bulan November Tahun 2017. Halaman: 1456-1468 (http://journal.um.ac.id/ index.php/jptpp/diakses, 12 April 2019)

Badan Penelitian dan Pengembangan. 2013. Pedoman Pelaksanaan Kurikulum 2013. Jakarta: Kementerian Pendidikan dan Kebudayaan.

Dick, Walter., Lou Carey \& James O. Carey. 2001. The Systemic Design of Instruction

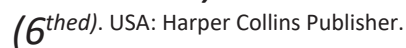

Ghufron, A. 2010. Integrasi Nilai-nilai Karakter Bangsa pada Kegiatan Pembelajaran. (Online), (http://journal.uny.ac.id/ index.php/cp/article/download/230/ pdf_23, diakses 10 April 2019).

Harun, 2017. Konsep dan Pedoman Penguatan Karakter. Jakarta; Tim Pengembangan PPK Kementrian Pendidikan dan Kebudayaan

Handayani, Agustina., Punaji Setyosari.,\& Sulthoni 2017. Pengembangan bahan ajar Biologi Berbasis Multimedia untuk Siswa VIII II SMP Islam Yakin Tutur Kabupaten Pasuruan. Jurnal Kajian Teknologi Pendidikan Edcomtech Volume 2, Nomor 1, April 2017. (http://journal2.um.ac.id/index.php/ edcomtech/article/view/2073/1218/ diakses 30 April 2019)

Ikhsan, 2017. Kecenderunagn Global dalam Proses Pembelajaran Pendidikan Pancasila dan Kewarganegaraan (PPKn). Jurnal Pancasila dan Kewarganegaraan. Universitas Muhammadiyah Ponorogo, Vol 2 No 2 Juli 2017: Halaman 49-58. http://journal.umpo.ac.id/index.php/ JPK/index. Diakses, 27 Maret 2019

Kurniasih, I., \& Berlin Sani. 2014. Panduan Membuat Bahan Ajar (Buku Teks Pelajaran) sesuai dengan Kurikulum 2013. Surabaya: Kata Pena.

Kemendikbud. 2013. MateriPelatihan Pendidik Impelementasi Kurikulum 2013. Jakarta: badan Pengembangan SDM Pendidikan dan kebudayaan dan penjaminan mutu Pendidikan Kementrian Pendidikan dan Kebudayaan

Kemendikbud, 2016. Panduan Gerakan Literasi di Sekolah Menegah Pertama (SMP). Jakarta; Tim Gerakan Literasi Kementrian Pendidikan dan Kebudayaan Lestari, Ika. 2013. Pengembangan Bahan Ajar Berbasis Kompetensi. Padang:Akademia Permata.

Majid, Abdul. 2013. Strategi Pembelajaran . Remaja Rosdakarya: Bandung.

Mbulu, J., \& Suhartono. 2004. Pengembangan Bahan Ajar. Malang: Elang Mas.

Prastowo, Andi. 2012. Panduan Kreatif Membuat Bahan Ajar Inovatif. Yogyakarta: Diva Press.

P. Resvathi S. A., Degeng, N. S dan Kuswansi, D. 2017. Pengembangan Paket Pembelajaran Penanganan Pascapanen Buah-Buahan Kelas XI Semester II SMKPP Negeri Banjarbaru. Edcomtech Vol. 2 (1), pp. 77-87. Diakses.April 2019

Ridwan, M., Sahat Siagian. 2016. Pengembangan Bahan Ajar Pada Mata pelajaran PPKn. Jurnal Teknologi Informasi \& Komunikasi dalam Pendidikan, Vol. 3, No. 2. Desember 2016 halaman167-180. Diakses, 13 April 2019.

Suyono. 2009. Pembelajaran Efektif dan Produktif Bebasis Literasi: Analisis Konteks, Prinsip, dan Wujud Alternatif Strategi Implementasinya di Sekolah. Jurnal Bahasa dan Seni, Tahun 37, Nomor 2, Agustus 2009. Halaman 203218.

Wibowo, A. 2013. Manajemen Pendidikan Karakter di Sekolah. Yogyakarta: Pustaka Pelajar.

Wahyuni, Eka., I Nyoman Sudana Degeng., Nurmida, C. Sitompul. (2018), Pengembangan Bahan ajar Tematik Pendamping Guru Dengan Model Webbed Untuk Sekolah Dasar Kelas 2. Jurnal Kajian Teknologi Pendidikan Edcomtech. Vol. 3 No. 22018. http://journal2.um.ac.id/index.php/ edcomtech/article/view/5084. Diakses, 11 April 2019. 